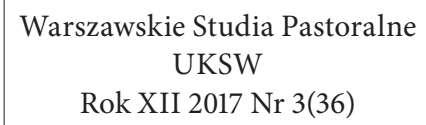

Prof. ThDr. Ladislav Csontos SJ, PhD.

Trnavská univerzita $v$ Trnave, Teologická fakulta

\title{
INICIATÍVY NOVEJ EVANJELIZÁCIE NA SLOVENSKU
}

New Evangelization Initiatives in Slovakia

Slovenská republika síce patrí k tradične katolíckym krajinám Európy, ktorá v druhej polovici dvadsiateho storočia prežila tvrdé prenasledovanie Cirkvi. Od zmocnenia sa vlády komunistami v bývalom Česko-Slovensku politickým prevratom vo februári 1948 rozpútala nová politická moc tvrdé prenasledovanie Katolíckej cirkvi. Vývoj smeroval k štátnemu zriadeniu, ktoré si nárokovalo kontrolu nad všetkými oblastami spoločenského, politického, kultúrneho, ale aj náboženského života. Smernice z mája 1948 nariadili odstránit’ kríže zo škôl, zrušili vyučovanie náboženstva na stredných školách. Nariadili, že každý druh vzdelania a výchovy musí byt' v súlade ludovodemokratickým duchom a že štát má právo na ich kontrolu, čo bolo namierené proti cirkevným internátom a súkromným školám, ktoré ešte existovali ${ }^{1}$. Kardinál Korec o tejto dobe vydal nasledujúce svedectvo: „Už v júni roku 1948 sa konala v Karlových Varoch dôležitá porada predstavitelov vlády o cirkevnej politike. Tam sa rozhodlo, ako pokračovat’ v cirkevnej politike: »Obmedzit činnost' biskupov, izolovat' ich od kléru, obmedzit’ vplyv Vatikánu, uviest' novú Katolícku akciu, zaviest’ úrad pre cirkevné veci, podporovat' kňazov, ktorí dávajú a plnia socialistické záväzky. Cirkev katolícku premieňat’ postupne na Cirkev národnú, zasiahnut do katolíckych ustanovizní, odstraňovat' horlivých kňazov...« A potom nasledovala jedna Jóbova zvest’ za druhou... vláda

1 Por. J. M. Dubovský, M. Fedor, I. Chalupecký, E. Krapka, V. Mikula, G. Povala, H. Radváni, J. Šimončič, Dejiny Spoločnosti Ježišovej na Slovensku, Trnava 1990, s. 396. 
siahla na cirkevný. majetok, poštátňuje d’alšie školy, ruší katolícke časopisy... zakazuje Združenie katolíckej mládeže, ruší aj vydavatel'stvá Spolku sv. Vojtecha, Posla, Verbum a iné... Koncom roku 1948 bola zatvorená vel’mi cenná inštitúcia »Ústredná katolícka kancelária« so sídlom v Bratislave. Boli zakázané i d’alšie organizácie - katolíckych žien, mužov...Napriek všetkým tvrdým opatreniam a zásahom proti Cirkvi, žiadalo sa od biskupov, aby opätovne vydávali vyhlásenia na podporu vlády. Arcibiskup Beran v obežníku z 29. apríla 1949 preto napísal: »Nie sme ochotní kedykolvek a pri každej príležitosti vydávat’ opätovné politické vyhlásenia... Našou úlohou je spása nesmrtelných duší. "Medzitým, čo boli zastavené katolícke časopisy rušené cirkevné školy a spolky, okolo 70 kňazov bolo vo väzení, spolu niekol'ko sto laikov..." 2 .

Vláda „dekrétom č. 112 zo 14. júla 1950 zrušila 13 diecéznych seminárov a ponechala len fakultu v Bratislave a v Prahe. Počet seminaristov poklesol na $10 \%$ “3. Tomuto opatrenie predchádzala v noci z 13. na 14. apríla likvidácia mužských reholí. Bolo zlikvidovaných 16 mužských reholí s 1019 rehol’níkmi v 96 kláštoroch, bolo znemožnené prijímanie novicov. Následne boli zlikvidované aj ženské rehole, ktorých bolo 24 so 4253 reholnými sestrami, ktoré pôsobili v 168 kláštoroch, pričom viedli mnohé školy a vel'ké nemocnice ${ }^{4}$. Zostávala totálne oklieštená farská pastorácia obmedzená na vysluhovanie sviatostí a obmedzené vyučovanie náboženstva na základných školách. Štátny teror dosiahol svoje maximum v spojení s množstvom inscenovaných procesov proti biskupom, rehol'ným prestaveným,

2 J.Ch. Korec, Od barbarskej noci, Bratislava 1990, s. 52-53. Pozri tiež: J. Dolinský, Alternatívne vzdelávanie a výchova mimo fakulty a seminára, in: Katolícka bohoslovecká fakulta v Bratislave 1936-1989, Trnava 2011, s. 196-206.

3 J. Dolinský, Cirkevné dejiny Slovenska II, Trnava 2002, s. 87. Tiež: J. Dolinský, Arcibiskup Eduard Nécsey - život stálej adorácie, in: „Viera a život“ r. 23, č. 3, 2013, s. 27-30. J. Dolinský, Biskup Róbert Pobožný: úsilie o pokoj a jednotu v t’ažkej dobe, in: „Viera a život“ r. 22, č. 6, 2012, s. 34-37.

4 Por. V. Judák, Historický prierez desatročnej činnosti Konferencie biskupov Slovenska, in: Katolícka cirkev na Slovensku, www.kbs.sk/obsah/sekcia/h/konferencia-biskupov-slovenska/p/historicky-prierez [13.7.2016]. 
kňazom i laikom ${ }^{5}$. „Súčasne s prípravami na likvidáciu kláštorov prebiehala takzvaná akcia »P« (pravoslávie). Išlo o násilné včlenenie gréckokatolíckej cirkvi do pravoslávia. Jedným z prvých krokov bolo zatknutie biskupov Pavla Gojdiča a Vasila Hopku. Zinscenovaný "prešovský sobor" sa uskutočnil 28. apríla $1950^{“ 6}$. Na ňom bola gréckokatolícka cirkev rozpustená a jej duchovní a veriaci boli nútení prijat pravoslávnu vieru. Nasledovalo prenasledovanie kňazov a veriacich, ktorí zostali verní katolíckej viere. Len diecéznych kňazov, ktorí sa dostali roku 1950 mimo pastoráciu (izolácia, sústredovacie tábory, väzenie), bolo vyše 300. Až roky 1968-69 znamenali určité uvolnenie $\mathrm{v}$ prenasledovaní no došlo iba k úradnému obnoveniu gréckokatolíckej cirkvi 13. júna $1968^{7}$. Vyučovanie náboženstva na základných školách zostalo nadalej obmedzené ako i prijímanie do štátom kontrolovaného kňazského seminára v Bratislave. V období prenasledovania sa vytvorili dôležité neoficiálne štruktúry života Katolíckej cirkvi na Slovensku, ku ktorým patrili tajne fungujúce rehole a rozličné formy laického apoštolátu. Pád komunistického režimu priniesol vonkajšiu slobodu a potrebu obnovy riadnych cirkevných štruktúr spojených s novou evanjelizáciou Slovenska, v ktorých možno vybadat dve základné tendencie plošnú a špecializovanú, ktoré narážajú na spoločné tažkosti a potrebu zmeny na farskej úrovni.

\section{Plošné projekty}

Prvým plošným projektom bolo „Desatročia duchovnej obnovy Slovenska, ktorá bola vzdialenou prípravou na Jubilejný rok $2000^{“ 8}$. Konferencia biskupov vydávala metodické materiály pre farárov a správcov farností, ktoré prinášali témy na jednotlivé mesiace a boli

\footnotetext{
${ }^{5}$ Por. J.Ch. Korec, Od barbarskej noci, op. cit., s. 65-70.

6 J. Dolinský, Cirkevné dejiny Slovenska II, op. cit., s. 88.

7 Por. tamže, s. 94.

8 V. Judák, Historický prierez desat'ročnej činnosti Konferencie biskupov Slovenska, in: Katolícka cirkev na Slovensku, www.kbs.sk/obsah/sekcia/h/konferencia-biskupov-slovenska/p/historicky-prierez [13.7.2016].
} 
tiež uverejňované v katolíckych časopisoch ${ }^{9}$. Desatročie do roku 2000 bolo charakteristické najmä obnovou a vybudovaním riadnych cirkevných štruktúr. Bolo vybudovaných niekol'ko sto nových kostolov, ktorých stavba za predchádzajúceho režimu nebola možná.

Už po svojom nástupe na čelo Spišskej diecézy biskupa Mons. František Tondra na prvých kňazských rekolekciách v jeseni 1989 hovoril o zámere zvolat diecéznu synodu, ktorá by sa stala nástrojom zjednotenia a systematickej organizácie duchovného života tejto partikulárnej cirkvi. V rokoch, ktoré nasledovali, sa však tažisko pastoračnej práce tak v diecéze ako aj v ostatných diecézach Slovenska sústredilo na zriad’ovanie patričných štruktúr, úradov a inštitúcií. Súčasne sa na Slovensku prakticky v celých 90-tych rokoch hovorilo o tom, že bude najskôr usporiadaný celoslovenský cirkevný snem a od jeho výsledkov sa budú odvíjat diecézne aktivity podla úvah jednotlivých biskupov v tomto smere ${ }^{10}$. Napokon sa však uskutočnili diecézne synody v diecézach: Banská Bystrica v rokoch 2003-2005, Košice v rokoch 2004-2006, Spiš v rokoch 2006-2011 11. Od roku 2015 prebieha diecézna synoda Ordinariátu ozbrojených síl a ozbrojených zložiek Slovenskej Republiky s predpokladaným termínom ukončenia v roku $2017^{12}$.

Slovenskí jezuiti od roku 1992 usporiadali desat interdisciplinárnych sympózií na rozličné témy so spoločným titulom Nová evanjelizácia. Nik z účastníkov nepochyboval o správnosti témy, respektíve výzvy sv. pápeža Jána Pavla II. o potrebe novej evanjelizácie, či reevanjelizácie Európy ako i Slovenska. Na druhom ročníku otec biskup František Rábek vyzdvihol potrebu evanjelizovat farnost', pričom

9 Por. F. Rábek, Kristovo posolstvo (téma duchovnej obnovy na máj), in: „Slovo Dvojtýždenník gréckokatolíckej cirkvi“ roč. XXIV. 1992, č. 10 s. 3.

10 Por. Dokumenty Druhej synody spišskej diecézy, Spišská Kapitula 2011, s. 11-12.

11 Por. tamže, s. 11.

12 Por. F. Rábek, Dekrét o vyhlásení synody. Marianka: Ordinariát ozbrojených síl a ozbrojených zborov Slovenskej republiky 2015, www.ordinariat.sk/data/files/3085_dekret-o-vyhlaseni-synody.pdf [13.7.2016]. 
ako klúč označil potrebu evanjelizovat kňazov a aktívnych laikov ${ }^{13}$. Vo svojom príspevku podal aj popis východiskového stavu a ciel,' potrebu zlepšenia, ktorú charakterizoval ako výzvu, aby sa farnost’ stala spoločenstvom spoločenstiev ${ }^{14}$. Konferencia biskupov Slovenska pracovala na celoplošných projektoch „Pastoračný a evanjelizačný plán katolíckej cirkvi na Slovensku pre roky“ 2001-2006 a 2007-2013. Boli to dva kvalitne vypracované evanjelizačné a pastoračné plány Katolíckej cirkvi na Slovensku.

Po dvadsiatich rokoch dvojica pastorálnych teológov Jozef Žuffa a Zdenko Pupík realizovala medzi kňazmi anketu o potrebe pastoračného plánovania. Jeden respondent zhodnotil spoluprácu diecézy s farnostami slovami: „Nepamätám si v ostatnom čase, že by z úst niektorého cirkevného predstaveného zaznel vôbec pojem Pastoračný plán, že by v našich katolíckych masmédiách sa vysielala relácia, diskusia na túto tému. Ak v roku 2013 skončilo obdobie Pastoračného plánu, nikde sme nepočuli nič o zhodnotení daného plánu a evaluácia je vel’mi potrebná “15. Ukázalo sa, že v plošných akciách boli privel'ké očakávanie ale skromné výsledky. Napriek tomu boli vytvorené cenné dokumenty a samotný proces ich tvorby bol obohatením pre tvorcov. Tento proces priniesol aj široký priestor pre vedeckú a odbornú diskusiu. Ukázalo sa, že v menších aktivitách boli dosiahnuté relatívne väčšie výsledky a najmä spontánne iniciatívy mali väčšiu plodnost'. $\mathrm{V}$ pastoračnom plánovaní sa ukázali aj viaceré nedostatky a to predovšetkým absencia kontroly v plánovaní. U kňazov nedostatok vlastnej iniciatívy a potreby niečo vo svojej pastoračnej práci zmenit’ alebo zlepšit', tiež malá kontinuita vo farskej pastorácii, ked’ nový správca farnosti začína akoby od nuly bez nadviazania na výsledky práce svojich predchodcov. Striedanie rozličných typov správcov farností, ktorí sú niekedy privel’mi autoritatívni a málo kooperatívni.

\footnotetext{
13 Por. F. Rábek, Farnost'-miesto a východisko evanjelizácie, in: Nová evanjelizácia. Zborník sympózia s medzinárodnou účastou II: ročník, Trnava 1993, s. 138.

14 Por. tamže, s. 139.

15 Z. Pupík, J. Žuffa, Vidiet', hodnotit'konat, Pastoračné plánovanie vo farnostiach, Trnava 2015, s. 58.
} 


\section{Špeciálne projekty}

V nadväznosti na sympózií so spoločným titulom Nová evanjelizácia, ktoré sa postupne venovali témam potreby novej evanjelizácie všeobecne a následne špecifickým témam mládež, rodina, seniori, chorí, farnost', kňazská formácia, krestanská kultúra, elektronické médiá, misie ${ }^{16}$, bol na Teologickej fakulte Trnavskej univerzity spustený projekt Skvalitnenie vyučovania pastorálnej teológie. V jeho rámci bol v roku 2007 uskutočnený „Výskumu religiozity katolíkov na Slovensku“. Išlo o prístup modernej pastorálnej teológie, ktorá potrebuje spoluprácu s empirickými vedami, ako je psychológia, politológia a sociológia. Výsledky výskumu boli spracované metódou pastorálnej teológie, prevzatej od zakladatela francúzskeho hnutia robotníckej mládeže JOC abbé Cardijna (1882-1967): vidiet' - posúdit’ - konat' (voir - juger - agir). Takto pastorálna teológia obsahuje tieto tri aspekty: aspekt kairologický, aspekt kriteriologický a aspekt praxeologický, ktorý je pre ňu klúčový ${ }^{17}$.

Jeden dôležitý praktický problém, na ktorý poukázal výskum v oblasti odovzdávania viery v rodine je slabá účast’ otcov na ňom. Deti učili modlit’ sa hlavne matky, staré matky a kňazi, mladšiu generáciu katechéti. Viac ako polovica otcov chodila menej často na sv. omšu ako raz do týždňa. V oblasti rodinného života a reprodukčného správania sa vo všetkých sledovaných oblastiach prejavil vel'mi pozitívny vplyv religiozity podla všetkých sledovaných ukazovatel'ov. Kvôli spresneniu údajov o vplyve religiozity sa overoval súčasný možný vplyv d’alších faktorov, ktoré môžu ovplyvňovat' hodnotu prisudzovanú manželstvu, postoje $\mathrm{k}$ mimomanželskému spolužitiu a dalšie sledované ukazovatele rodinného života. Ukázal sa významný vplyv religiozity na chápanie rodinného života a reprodukčné správanie obyvatel'stva. Je to dôležité znamenie, že negatívnym vplyvom na rodinu možno čelit iba nepriamo, a to prehlbovaním a skvalitňovaním

\footnotetext{
16 Por. J. Ďurica, J. Kyselica, Od prípravy synody o novej evanjelizácii po jej uvádzanie do života, Trnava 2014, s. 16-17.

17 Por. L. Csontos, J. Matulník, Zhrnutie, in: J. Matulník a i.: Analýza religiozity katolíkov na Slovensku: Poznatky zo sociologického výskumu, Bratislava 2008, s. 305.
} 
náboženského života veriacich. Objavila sa aj menej priaznivá skutočnost', že i v tomto výskume sa prejavila pomerne vysoká miera benevolencie obyvatelov Slovensku, i veriacich, ku kohabitáciám, k sexuálnym stykom maloletých i k hormonálnej antikoncepcii ${ }^{18}$.

Druhý dôležitým výskumom v rámci projektu Skvalitnenie vyučovania pastorálnej teológie bol „Výskum religiozity mladých katolíkov na Slovensku vo veku 17 rokov“, ktorý realizoval v školskom roku 2012/13 riešitel'ský kolektív pod vedením sociológa profesora Jozefa Matulníka. Zaujímavé sú výsledky ohladom rozhodnutie pre kňazské resp. reholné povolanie. Toto rozhodovanie je zvyčajne niekol'koročný rozhodovací proces, na ktorý vplývajú viaceré vnútorné i vonkajšie faktory. Tomu zodpovedajú výsledky výskumu: 0,9\% áno a 1,9\% skôr áno v odpovedi na otázku: Chceli by ste vy vykonávat kňazské, resp. reholné povolanie? Odpoved' skôr áno signalizuje, že mladý človek je v rozhodovacom procese pravdepodobne už dost' d'aleko, čo vzbudzuje nádej a je výzvou pre ohlasovanie evanjelia v celej jeho plnosti dnešným mladým lud’om, lebo aj z nich si chce Boh povolat’ tých, ktorí sú potrební do jeho žatvy ${ }^{19}$. Vážne sú zistenia výskumu, ktoré poukazujú na vel’mi permisívne postoje ku kohabitáciám u študentov i u matiek a na druhej strane na pozitívny vplyv religiozity na tieto postoje. S názorom, že je vhodné, aby muž a žena pred vstupom do manželstva najprv spolu určitý čas žili na „na skúšku“ súhlasilo vo výskume až $84,5 \%$ študentov. Je to oblast', v ktorej sa dlhodobo ukazujú slabiny katechézy a pastorácie mládeže. Vo výskume sa tiež potvrdilo, že respondenti, ktorých charakterizuje vyššia religiozita vo väčšej miere odmietajú kohabitácie i sexuálne styky neplnoletých ako menej religiózni respondenti, týka sa to najmä osobnej modlitby,

\footnotetext{
18 Por. J. Matulník, M. Kratochvíla, J. Kyselica, Religiozita, rodina a reprodukčné správanie obyvatelov Slovenska, in: J. Matulník, a i.: Analýza religiozity katolíkov na Slovensku: Poznatky zo sociologického výskumu, Trnava 2008, s. 223.

19 Por. L. Csontos, Vztảh ku kňazskému povolaniu, in: J. Matulník, Analýza religiozity mladých katolíkov na Slovensku Poznatky zo sociologického výskumu, Trnava 2014, s. 55-72.
} 
frekvencie prijímania sviatosti zmierenia a eucharistie a intenzity účasti na živote farského spoločenstva ${ }^{20}$.

Zaujímavých je okruh zistení ohladom rodinného prostredia mladých katolíkov vo veku 17 rokov. Rodinnú atmosféru hodnotia dve tretiny respondentov pozitívne. Dôležitú úlohu hrá prítomnost’ vlastného otca, ked’ respondenti z týchto domácností častejšie praktizujú vieru a taktiež predpokladajú, že budú chodit do kostola, ked' budú mat' 25 rokov. Podobnú dôležitú úlohu v rodine zastávajú i starí rodičia. Deti z domácností, v ktorých žije minimálne jeden starý rodič, chodia častejšie do kostola, predpokladajú, že ho budú navštevovat aj ako 25-roční. Títo respondenti sa tiež cítia viac spätí so svojím farským spoločenstvom $^{21}$. Nie vel'mi prekvapujú zistenia výskumu ohladom vplyvu elektronických médií na mladých. Muži celkovo využívajú médiá počas dňa výrazne viac než ženy. Hranie počítačových hier u mladých a taktiež ich záujem o mediálne obsahy zamerané na hry vel’mi úzko súvisí s ich menej intenzívnou prípravou na vyučovanie, horšími známkami a menej intenzívnou komunikáciou s rodičmi o citlivých otázkach. U mladých katolíkov je hranie počítačových hier tiež v negatívnom vztahu s ich súkromnou a verejnou náboženskou praxou - menej sa modlia, menej často chodia do kostola a celkovo je pre nich náboženstvo menej dôležité22. Mnohé z týchto výziev sú podnetom na skvalitnenie vyučovania pastorálnej teológie najmä v oblasti začleňovania veriacich do spoločenstva Cirkvi. Ukazuje sa potreba budovat farské spoločenstvá ako spoločenstvo spoločenstiev ${ }^{23}$.

Novými výzvami, ktoré stoja pred Katolíckou cirkvou sú osobitne reflektované v monografii Jána Ďuricu SJ a Jozefa Kyselicu SJ: Od

\footnotetext{
20 Por. J. Matulník, M. Kratochvíla, Postoje ku kohabitáciám, in: J. Matulník, Analýza religiozity mladých katolíkov na Slovensku Poznatky zo sociologického výskumu, op. cit., s. 159-171.

21 Por. M. Kratochvíla, Rodinné prostredie, in: J. Matulník, Analýza religiozity mladých katolíkov na Slovensku Poznatky zo sociologického výskumu, Trnava 2014, s. 119-157.

22 Por. M. Fero, Médiá, in: J. Matulník, Analýza religiozity mladých katolíkov na Slovensku Poznatky zo sociologického výskumu, op. cit., s. 229-296.

23 Por. J. Kyselica, Odovzdávat’ vieru v súčasnej spoločnosti, Trnava 2006. s. 122.
} 
prípravy synody o novej evenjelizácii po jej uvádzanie do života. „Po roku 1989 sa pre všetkých ludí otvorila vel'ká možnost’ objavenia alebo rozvíjania viery, tak u pokrstených, ako aj nepokrstených alebo vzdialených od Cirkvi. Pri vel'kej zat’aženosti kňazov na mnohých miestach misijnej práce sa zapájajú aj laici. Spoluúčast' laikov je však vel’mi čiastočná. Niekedy sa vytvára určitá obava a cirkevné dokumenty sa neberú vo všetkom dost’ dôsledne ${ }^{\text {“24 }}$. Význam hnutí a spoločenstiev vyzdvihujú na príklade farnosti Banská Bystrica - Radvaň, kde pôsobil P. Ján Ďurica SJ. „Z osobnej skúsenosti môžem potvrdit, že spolupráca s charizmatickými spoločenstvami, vrátane vyučovania náboženstva na školách a bežnej pastorácie v priebehu desiatich rokov, zo skoro mŕtvej farnosti zo 40 tisíc obyvatel'mi vznikli dalšie dve farnosti s novo postavenými kostolmi. Z dvoch sv. omší v nedelu je teraz dvanást' ${ }^{\text {‘25. }}$.

Medzi špeciálnymi iniciatívam si zasluhujú povšimnutia evanjelizačný festival gospelovej hudby „Lumen“ v Trnave, ktorý organizujú pre mládež slovenskí saleziáni. Okrem vystúpení domácich a zahraničných kapiel prináša bohatý sprievodný program prednášok svedectiev a dialógov. V roku 2016 sa konal už 24. ročník ${ }^{26}$.

Slovenskí františkáni zriadili na základe potreby reevanjelizácie krestanov v strednom veku na Slovensku v bývalom františkánskom kláštore v Beckove Centrum novej evanjelizácie sv. Jána Pavla II. Uskutočňujú modlitby za uzdravenie a napomáhajú rozvoj malých spoločenstiev. Jeho víziou je:

- pomôct' objavit' krestanom vlastnú identitu Otcovho syna a dcéry, královského dietata so všetkými jeho právami a privilégiami

- prinášat' uzdravenie a slobodu Božím detom ${ }^{27}$.

\footnotetext{
24 J. Ďurica, J. Kyselica, Od prípravy synody o novej evenjelizácii po jej uvúdzanie do života, op. cit., s. 13.

25 Tamže, s. 31.

26 Buletin festivalu Lumen 2016, www.fln.sk/2016/wp-content/uploads/buletin-festival-web.pdf [13.7.2016].

27 Por. Centrum novej evanjelizácie Beckov, http://cne-beckov.sk/sk_SK/ (13.7.2016).
} 
Spoločenstvo pri dóme sv. Martina v Bratislave vzniklo ako iniciatíva laikov, ktorá sa stretala na dómskej fare a v lete roku 1993 zažili zakladajúci členovia počas duchovných cvičení vo francúzskom mestečku Paray le Monial vyliatie Ducha Svätého. Odvtedy spoločenstvo začalo rást', a preto sa začalo stretávat’ vo väčších priestoroch. Popri vlastných stretnutiach začala rásṫ aj služba na rôznych úrovniach. Evanjelizácia, vydávanie krestanského časopisu Nahlas, duchovné obnovy pre rôzne skupiny atd'. Toto všetko bolo a stále je sprevádzané mnohými svedectvami ludí o ich osobnom obrátení k Ježišovi a zmene životov. Spoločenstvo vyvíja iniciatívy aj oblasti verejného života, viacerí jeho členovia vstúpili do politiky a niektorí sú aj europoslancami ${ }^{28}$.

Na Slovensku intenzívne pôsobí Katolícka charizmatická obnova. Obnova sa usiluje prispiet’ k obráteniu, spáse a posväcovaniu všetkých ludí a $\mathrm{k}$ ich zjednoteniu v účinnom spoločenstve Božieho ludu. Záleží jej na tom, aby každé dielo v Cirkvi bolo založené na rozpoznávaní Božích zámerov a plánov. Kladie dôraz na: poznanie Boha ako milujúceho a odpúštajúceho Otca, nadviazanie osobného vztahu s Ježišom, potrebu posilňovat’ v sebe prítomnost’ Ducha Svätého, dôležitost' Svätého písma, sviatostí, bohoslužby, modlitby, modlitby chvál, dôležitost' chariziem alebo darov Ducha Svätého pre službu Cirkvi, potrebu budovat' spoločenstvo, poslanie ohlasovat' evanjelium a vydávat' svedectvo. Pôsobí vo všetkých diecézach a od roku 2004 vydáva časopis Charizma ${ }^{29}$. Vo výpočte by sme mohli pokračovat d’alej no klúčovým sa ukazuje obnova farského spoločenstva v ktorej je klúčovou osobou duchovný správca farnosti.

\section{Obnova farského spoločenstva}

Druhý vatikánsky koncil zdôraznil starobylé učenie, že Cirkev je vo svojej podstate spoločenstvo. Jozef Kulisz pripomína výroky cirkevných otcov o spoločenstve Cirkvi o Komunii (koinonia), na

\footnotetext{
28 Por. Martindom Spoločenstvo pri dóme sv. Martina v Bratislave, www.martindom. sk/index.php?id=377\&type=md_main_menu\&t=7 [13.7.2016].

29 Por. Katolícka charizmatická obnova, www.kcho.sk/obnova.php [13.7.2016].
} 
ktorých buduje svoju náuku koncilová konštitúcia o liturgickej obnove Sacrosanctum concilium. „Podla Jána Damascénskeho je jednota krestanov vyjadrená Pánovou obetou, ked' Pán nazýva svoje telo chlebom, ktorý vznikol z množstva zŕn, a víno svojou krvou, ktoré vzniklo z mnohých bobúl. To vyjadruje, že krestanské spoločenstvo vzniklo z mnohých osôb, ktoré sa zjednocujú Telom a Krvou Kristovou a tvoria jeho Tajomné Telo. Naznačuje aj myšlienku sv. Cypriána, ktorá vyjadruje jednotu krestanom založenú v eucharistii “30. V roku 1993 vo svojom referáte na sympóziu Nová evanjelizácia Marián Kováčik konštatoval, že cielom súčasnej pastorácie je priviest' ludí k prvému svätému prijímaniu a potom tento stav udržiavat'. Všetko je zamerané akoby len na jeden ciel' - aby ludia chodili na prijímanie. Ako pokus o nový model farnosti, ktorý však nezostáva iba modelom, ale stáva sa realitou vo farnostiach v Pol'sku, uviedol model farnosti ako spoločenstva spoločenstiev podla prof. Blachnického zakladatela hnutia Svetlo-Život. Cielom modernej pastorácie vo farnosti by sa malo stat vovedenia do života farského spoločenstva, v ktorom sa prijímajú sviatosti, no jej život sa nevyčerpáva iba v ich prijímaní ${ }^{31}$. Toto spoločenstvo sa realizuje vo farnosti ako husej sieti osobných vztahov, kde duchovný pastier spĺn̆a osobitné poslanie ${ }^{32}$.

Je vhodné porovnat požiadavky Kódexu kánonického práva: „Farár je povinný starat’ sa, aby sa Božie slovo celostne hlásalo tým, ktorí sa nachádzajú vo farnosti; preto má dbat’ o to, aby laickí veriaci boli poučovaní o pravdách viery najmä homíliou, ktorú treba konat’v nedele a prikázané sviatky, ako aj katechetickou výukou, a má rozvíjat diela, ktorými sa napomáha evanjeliový duch aj vo vztahu k sociálnej spravodlivosti; osobitnú starostlivost' má venovat katolíckej výchove detí a mládeže; má sa aj za spolupráce veriacich všemožne usilovat', aby sa evanjeliové posolstvo dostalo aj k tým, ktorí zanechali uplatňovanie

\footnotetext{
30 J. Kulisz, Eucharystia sakramentem jedności w rozumieniu Teilharda de Chardin, in: „Studia Theologica Varsaviensia” 2000, roč. 38, č. 2, s. 141.

31 Por. M. Kováčik, Evanjelizácia ako prvá etapa budovania farnosti, in: Nová evanjelizácia II, Bratislava 1993, s. 87.

32 Por. J. Kyselica, Odovzdávat’ vieru v súčasnej spoločnosti, Trnava 2006, s. 90.
} 
náboženstva alebo nevyznávajú pravú vieru“ (KKP kán. 528 \$1). Kódex celkom jasne hovorí o tom, že farár často nemôže osobne zvládnut v plnej miere všetky spomenuté povinnosti, preto ho nasledujúci kánon zaväzuje: „Farár má uznávat’ a napomáhat’ vlastný diel, ktorý majú v poslaní Cirkvi laickí veriaci, podporujúc ich združenia s náboženskými ciel'mi. Má spolupracovat’ so svojím biskupom a s presbytériom diecézy a vynasnažovat’ sa, aby sa veriaci starali o farské spoločenstvo, aby sa cítili členmi tak diecézy, ako aj celej Cirkvi a aby sa na dielach, ktoré toto spoločenstvo majú napomáhat', zúčastňovali alebo ich podporovali (KKP kán. $529 \$ 2$ ).

Dôležité je však aj subjektívne hladisko osoby, v tomto prípade správcu farnosti, či vníma potrebu zmeny vo svojej pastoračnej práci. Motivácia k zmene je ako na to vo všeobecnosti upozorňuje teória manažmentu rozhodujúca pre plánovanie a rast v organizácii. Platí to aj vo farnosti, ako to výstižne charakterizoval biskup Rábek, ide o evanjelizáciu kňazov. Motivovaný správca farnosti si uvedomuje potrebu zmeny a hladania prostriedkov na jej uskutočnenie. Tu už môžu nastúpit základné funkcie manažmentu, ktorými sú: plánovanie; organizovanie; vedenie ludí; kontrola ${ }^{33}$.

Nemožno povedat', že by nejaká farnost’ nefungovala, no vždy je možné, aby fungovala lepšie tak, ako v osobnom duchovnom živote je vždy možný rast, tak isto je to možné aj v živote farského spoločenstva. Aj rozvoj života farského spoločenstva sa javí určitý cyklický proces, v ktorom sa popri duchovných prostriedkoch možno inšpirovat aj zásadami manažmentu kvality. Manažérstvo kvality sa zakladá na uplatňovaní praxou overených teoretických konceptov. Univerzálny model pre zlepšovanie kvality ponúkol W.E. Deming v podobe tzv. PDCA - cyklu ako cyklický nepretržitý proces, pozostávajúci z týchto krokov:

- P (plan) - plánovanie (analýza situácie, vypracovanie plánu, stanovenie kontrolných bodov).

- D (do) - vykonanie (oboznámenie a tréning pracovníkov, realizácia plánu).

33 Por. J. Mihok, P. Trebuńa, Základy manažmentu, Košice 2009, s. 20. 
- C (check) - preskúšanie (monitorovanie situácie, zistenie splnenia plánovaných cielov).

- A (act) - zlepšenie a následná štandardizácia pri súlade skutočnosti s plánom, resp. návrat $\mathrm{k}$ „ $\mathrm{P}^{\text {“ a }}$ „D“ pri nesúlade skutočnosti s plánom ${ }^{34}$.

Plánovanie je teda „osou“ riadenia. Je to proces, ktorého výsledkom má byt plán s tromi základnými zložkami: ciele, ktoré sa majú dosiahnut; špecifikácia činností potrebných na dosiahnutie cielov; prepočet (odhad) zdrojov potrebných na uskutočnenie činností. Všeobecné ciele, činnosti a prostriedky sú pomerne jasne stanovené $\mathrm{v}$ cirkevných dokumentoch a $\mathrm{v}$ Kódex kánonického práva, no je potrebné rozmenit ich na drobné konkrétne aktivity vo farnosti. Kódex ukladá farárovi alebo správcovi farnosti povinnosti, ktoré nemôže sám uskutočnit', no zároveň mu predkladá aj vnútorné zdroje farnosti, ktoré mu môžu a majú v tom pomáhat', sú to veriaci laici, ktorí majú byt členmi farskej pastoračnej rady a tiež majú nezastupitelné miesto v tom, aby sa ohlasovanie Božieho slova dostalo k tým, ktorí zanechali uplatňovanie náboženstva alebo nevyznávajú pravú vieru, ktorí sú v tažkých životných situáciách ako chudobní, utrápení, osamelí, vyhnaní z vlasti a takí, na ktorých doliehajú osobitné trápenia. Sú to tiež manželia a rodičia, ktorí by mali mat’ podporu pri plnení svojich povinností, a v rodine má podporovat vzrast krestanského života ako aj tí, ktorých katolícke manželstvo stroskotalo. Napokon, aby sa nik z členov farnosti necítil opustený, ale zahrnutý láskou veriaceho spoločenstva (porov. KKP kán. 526 až 537).

Ten istý kódex poskytuje aj dost' možností na kontrolu, bez ktorej nefunguje efektívne plánovanie, ktoré by viedlo k zmene. Spomenuli sme na začiatku vyjadrenie respondenta, správcu farnosti, pastoračnému plánovaniu chýba kontrola. Manažment považuje kontrolu za dôležitý prostriedok dosahovania stanovených cielov. Aj v tejto oblasti Kódex kanonického práva predkladá vel’mi účinný systém kontroly. Podla neho je povinnostou biskupov každých pät rokov

34 Por. E. Dudzinská, P. Budaj, Š. Vitko, Manažment v sociálnych službách, Prešov 2009, s. 225. 
vykonat návštevu Ad Limina Apostolorum, pri ktorej navštívia jednotlivé kongregácie a napokon sú prijatí na súkromných a spoločnej audiencii u Svätého Otca (por. KKP Kán $400 \$ 1$.) „Biskup je viazaný každoročne vizitovat’ diecézu, bud' celú, alebo jej čast’ tak, aby aspoň každých pät rokov vykonal vizitáciu celej diecézy sám, alebo ak by bol zákonne hatený, cez biskupa koadjútora alebo pomocného biskupa, alebo generálneho či biskupského vikára, alebo cez iného presbytera. Biskup si smie pri vizitácii vyvolit za sprievodcov a pomocníkov klerikov, akých chce“ (KKP Kán. 396). Pre tieto vizitácie majú biskupi vypracované dotazníky, ktoré však nie sú celkom dôsledné v kontrole všetkých povinností správcov farností. Tu vidíme priestor na zlepšenie, ako príklad by sme mohli uviest’ Žilinskú diecézu. Nič však nebráni v tom, aby bola kontrola častejšia. Má možnost̉ poverit’ dekanov vizitáciou farností svojho obvodu (por. KKP Kán. $555 \$ 4$ ). Teda pastoračné plánovanie by mohlo byt’ nielen možné ale aj efektívne, žiadalo by si to viac trpezlivosti.

Budúcnost’ bude závisiet’ od dobrej spolupráca kňaza s laikmi, ako si to žiada Kódex a ako sa to videlo potrebné už pred Druhým vatikánskym koncilom. V štyridsiatych rokoch dvadsiateho storočia na Slovensku požehnane účinkovali Mariánske kongregácie, ktoré boli zamerané nielen na vlastné posväcovanie ale aj na posvätenie iných, čiže apoštolát ${ }^{35}$. Očakávalo sa, že duchovní správcovia poskytnú členom kongregácií potrebnú apoštolskú formáciu po duchovnej aj intelektuálnej stránke a samotná kongregácia im poskytne zázemie živého spoločenstva ${ }^{36}$.

Napokon mi nedá pripojit niekol'ko starých, ale myslím osvedčených rád pre duchovných správcov Mariánskych kongregácií. „Často sa stáva, že práve tí chlapci sú najsúcejší vytvorit elitu, čo prézesovi robia

\footnotetext{
35 Por. Ako utvoríme elitu svetských vodcov, in: „Prézes“ 1940-41 roč. 1. č. 2. s. 116-119.

36 Por. Čnosti kongreganistu - apoštola, in: „Prézes“ $1940-41$ roč. 1. č. 3. s. 189; tiež Návrh na ročný program pre študentské Mariánske kongregície, in: „Prézes“ 1941 roč. 2. č. 1. s. 28.
} 
najviac »starostí« svojou neposednostou a huncútstvom. Len ich treba vediet' získat' zhovievavostou a porozumením. Vtedy svoju junácku silu aj sami obetujú Kristovým ideálom “37. Farnost' už nemôže byt beztvarou masou, ale potrebuje spomedzi laikov vodcovské osobnosti, ktoré strhnú masu a tvoria určitú elitu. „Kto sa zo zásady zrieka elity, zrieka sa masy “38.

Kňazom vo farskej pastorácii pri súčasnom vanutí Ducha Svätého v Cirkvi je osobitne inšpiratívny postreh: „Nie tá kongregácia je najlepšia, kde prézes chce alebo musí všetko sám robit. Práve naopak. Prézes tam má byt’ ako »Duch Boží, vznášajúci sa nad vodami«. Najideálnejší je prézes, čo všetko spravuje tak, že všetkým dá pracovat'. Dobrý prézes nechce využit svoje práva. Jeho úsilím je na zodpovedné miesta $\mathrm{v}$ kongregácii vybrat takých členov, čo si zaslúžia dôveru a pritom vedia samostatne pracovat. (...) Teda dajme čím väčšiemu množstvu možnost' pracovat'“39. To bude aj spôsob ako sa oživí farský život a farnost’ sa stane spoločenstvom spoločenstiev.

\section{Rezumé}

V Cirkvi na Slovensku bolo realizovaných niekol'ko celoplošných premyslených iniciatív: v devätdesiatych rokoch 20. storočia „Desatročie duchovnej obnovy“, dva „Pastoračné a evanjelizačné plány katolíckej cirkvi na Slovensku pre roky 2001-2006 a 2007-2013“. Na úrovni diecéz sa uskutočnili diecézne synody v diecézach Banská Bystrica, Košice, Spiš, Ordinariát ozbrojených síl a ozbrojených zložiek Slovenskej Republiky. Ďalšie iniciatívy vyvinuli Teologická fakulta Trnavskej univerzity na intelektuálnom poli organizáciou série desiatich sympózií „Nová evanjelizácia“ v rokoch 19922001 a rehole a hnutia katolíckych laikov. Napríklad: saleziáni evanjelizačný festival gospelovej hudby „Lumen“ v Trnave, tento rok bol už 24. ročník, františkáni „Centrum novej evanjelizácie sv. Jána Pavla II.“v Beckove, laici Spoločenstvo pri dóme sv. Martina v Bratislave, iniciatívy obnovy v Duchu Svätom a d’alšie. Ukázalo sa, že celoplošné iniciatívy mali viacero nedostatkov: privel'ké očakávania a slabá spätná väzba. Diecézne iniciatívy

\footnotetext{
37 Potreba našej doby a MK, in: „Prézes“ 1940-41 roč. 1. č. 4. s. 239.

38 Tamže, s. 240.

39 Tamže, s. 243.
} 
rozprúdili diskusiu a zastali pri vytvorení dokumentov, chýbala u väčšiny kňazov potreba uskutočnit nejaké zmeny vo svojej farnosti. Životaschopnými sa ukázali iniciatívy reholí a laikov, ktoré vyrástli spontánne, s tichou podporou biskupov. Klúčovú pozíciu v novej evanjelizácii vo farnosti majú kňazi, podla toho či podporujú apoštolát laikov, alebo ho brzdia. Už v štyridsiatych rokoch si to uvedomovali v ústredí Mariánskych kongregácií, že ich duchovní správcovia, prézesi, môžu život kongregácie podporovat’ ale aj hatit. Zdá sa, že to platí aj dnes o mnohých farnostiach, kde kňaz je klúčovou osobou pre naštartovanie novej evanjelizácie, či pastoračného obrátenia.

\section{Summary}

Several well planned nationwide initiatives have been implemented in the Slovak Catholic Church. The most significant of them are "The Decade of Spiritual Renewal" in the 1990s and two "Plans for Pastoral Care and Evangelization of the Catholic Church in Slovakia for the years 2001-2006 and 2007-2013." At the level of the dioceses diocesan synods were held in the dioceses of Banská Bystrica, Košice, Spiš, and the Ordinariate for the Armed Forces and the Armed Corps of the Slovak Republic. In the field of intellectual apostolate important initiatives were undertaken by The Faculty of Theology of Trnava University that organized a series of ten symposia on New Evangelization held in the years 1992-2001 as well as by various religious orders and Catholic lay movements. Among the examples of such initiatives are the Salesian evangelizing festival of gospel music "Lumen" in Trnava (its $24^{\text {th }}$ edition was held this year), the Franciscan "New Evangelization Centre of St. John Paul II" in Beckov, Lay Community at St. Martin's Cathedral in Bratislava, the initiatives of the Renewal in the Holy Spirit Movement and much more. It appears that nationwide initiatives had a number of shortcomings: they arouse excessive expectations and provided poor feedback. Diocesan initiatives triggered a lively debate which unfortunately only led to producing documents since the majority of priests did not perceive any need to implement the proposed changes in their parishes. In comparison with them, the initiatives of religious orders and laypeople which arouse spontaneously with a tacit support of the bishops proved to be much more viable. Priests are the key players in the new evangelization in parishes and its success depends on whether they support or hinder the lay apostolate. As early as in the 1940s the staff of the main office of Marian Congregations realized that their priests having the functions of spiritual directors and 
chairmen of local Congregations can support but also hinder their life. It appears that even today this holds true for many parishes where the priest is a key person in starting the processes of the new evangelization and pastoral conversion.

Klúčové slová: farské spoločenstvo, správca farnosti, evanjelizácia, laický apoštolát, charizmy

Key words: parish community, parish priest, evangelization, lay apostolate, charisms

\section{Bibliografia}

A ko utvoríme elitu svetských vodcov, in: „Prézes“1940-41 roč. 1. č. 2., s. 116-119. Buletin festivalu Lumen 2016, http://www.fln.sk/2016/wp-content/uploads/ buletin-festival-web.pdf [13.7.2016].

Centrum novej evanjelizácie Beckov, http://cne-beckov.sk/sk_SK/ [13.7.2016]. Dokumenty Druhej synody spišskej diecézy, Spišská Kapitula 2011.

Dolinský J., Cirkevné dejiny Slovenska II, Trnava 2002.

Dolinský J., Alternatívne vzdelávanie a výchova mimo fakulty a seminára, in: Katolícka bohoslovecká fakulta v Bratislave 1936-1989, Trnava 2011, s. 196-206.

Dolinský J., Arcibiskup Eduard Nécsey - život stálej adorácie, in: „Viera $a$ život" r. 23, č. 3, 2013, s. 27-30.

Dolinský J., Biskup Róbert Pobožný: úsilie o pokoj a jednotu v t’ažkej dobe, in: „Viera a život" r. 22, č. 6, 2012, s. 34-37.

Dubovský J. M., Fedor M., Chalupecký I., Krapka E., Mikula V., Povala G., Radváni H., Šimončič J., Dejiny Spoločnosti Ježišovej na Slovensku, Trnava 1990.

Dudzinská E., Budaj P., Vitko Š., Manažment v sociálnych službách, Prešov 2009.

Durica J., Kyselica J., Od prípravy synody o novej evanjelizácii po jej uvádzanie do života, Trnava 2014.

Judák V., Historický prierez desatročnej činnosti Konferencie biskupov Slovenska, in: Katolícka cirkev na Slovensku, www.kbs.sk/obsah/sekcia/h/ konferencia-biskupov-slovenska/p/historicky-prierez [13.7.2016].

Katolícka charizmatická obnova, in: http://www.kcho.sk/obnova.php [13.7.2016].

Korec J. Ch., Od barbarskej noci, Bratislava 1990. 
Kováčik M., Evanjelizácia ako prvá etapa budovania farnosti, in: Nová evanjelizácia II, Bratislava 1993, s. 87-90.

Kulisz J., Eucharystia sakramentem jedności w rozumieniu Teilharda de Chardin, in: „Studia Theologica Varsaviensia“2000, roč. 38, č. 2, s. 137-146.

Kyselica J., Odovzdávat vieru v súčasnej spoločnosti, Trnava 2006.

Martindom Spoločenstvo pri dóme sv. Martina v Bratislave, http://www.martindom.sk/index.php?id=377\&type=md_main_menu\&t=7 [13.7.2016].

Matulník J., a i.: Analýza religiozity katolíkov na Slovensku: Poznatky zo sociologického výskumu, Trnava 2008.

Matulník J., Analýza religiozity mladých katolíkov na Slovensku: Poznatky zo sociologického výskumu, Trnava 2014.

Mihok J., Trebuńa P., Základy manažmentu, Košice 2009.

Pupík Z., Žuffa J., Vidiet', hodnotit'konat', Pastoračné plánovanie vo farnostiach, Trnava 2015.

Rábek F., Kristovo posolstvo (téma duchovnej obnovy na máj), in: „Slovo Dvojtýždenník gréckokatolíckej cirkvi“ roč. XXIV. 1992, č. 10 s. 3-4.

Rábek F., Farnost' - miesto a východisko evanjelizácie, in: Nová evanjelizácia. Zborník sympózia s medzinárodnou účastou II: ročník, Trnava 1993, s. 134-140.

Rábek F., Dekrét o vyhlásení synody. Marianka: Ordinariát ozbrojených síl a ozbrojených zborov Slovenskej republiky 2015, http://www.ordinariat. sk/data/files/3085_dekret-o-vyhlaseni-synody.pdf [13.7.2016].

Prof. ThDr. Ladislav Csontos SJ, PhD. vyštudoval odbor matematika a deskriptívna geometria na Prírodovedeckej fakulte Univerzity Komenského v Bratislave. Filozofiu a teológiu študoval na tajne pôsobiacom jezuitskom teologickom inštitúte na Slovensku. Doktorát posvätnej teológie na Rímskokatolíckej cyrilometodskej fakulte Univerzity Komenského v Bratislave v roku 1995 a v roku 2001 riadnu profesúru na Cyrilometodějskej teologickej fakulte Univerzity Palackého v Olomouci. Pôsobí na Teologickej fakulte Trnavskej univerzita v Trnave so sídlom v Bratislave, kde prednáša logiku, antropológiu a filozofiu kultúry, vedecký výskum sústreduje na otázky pastorácie rodiny zvlášṫ katolíkov, ktorí žijú v iregulárnych situáciách. Má za sebou bohatú publikačnú činnost', ktorá obsahuje viac ako štyristo pozícií. Kontakt: Trnavská univerzita, Teologická fakulta, Kostolná 1, P.O. Box 173, SK-81499 Bratislava, Slovenská republika e-mail: ladislav.csontos@truni.sk. 